\title{
Postglacial reactivation of the Suasselkä PGF complex in SW Finnish Lapland
}

\author{
Antti E. K. Ojala ${ }^{1}$. Jussi Mattila ${ }^{1} \cdot$ Timo Ruskeeniemi $^{1} \cdot$ Jukka-Pekka Palmu ${ }^{1} \cdot$ Nicklas Nordbäck $^{1} \cdot$ Jukka Kuva $^{1}$. \\ Raimo Sutinen ${ }^{2}$
}

Received: 20 November 2018 / Accepted: 24 February 2019 / Published online: 4 March 2019

(C) The Author(s) 2019

\begin{abstract}
The Suasselkä fault complex is recognized from high-resolution digital elevation models (LiDAR DEMs) as a complex of 37 surface ruptures striking SW-NE and cutting through Weichselian glacial sediments, confirming the postglacial nature of the rupturing event. The analysis of LiDAR DEMs, geophysical profiles and trenching of glacial sediments at two sites along the Suasselkä postglacial fault (PGF) system has provided evidence of earthquakes that post- and predate the Late Weichselian deglaciation. At the Suaspalo trenching site, at least two different rupture events are observed: the first one predates the deposition of the lowermost till unit and potentially dates to the Early or even pre-Weichselian. The second rupture event, on the other hand, deforms overlying tills and is thus a post-Weichselian event. Our results indicate that multiple rupturing events can take place within 'postglacial fault complexes', which is the second time such a characteristic has been proven for PGFs in northern Fennoscandia. Furthermore, the present results provide the first evidence of either Early or even pre-Weichselian faulting in Finland, suggesting that the same fault complexes were also active after glacial phases that predated the last glacial maximum of the Late Weichselian. These results warrant re-evaluation of the long-term seismic risk associated with the faults as the assumption of single rupture events is erroneous. Considering that the Suasselkä PGF complex is composed of four PGF systems and 37 isolated 150-7500-m-long segments, we calculated the potential moment magnitudes based on the rupture length and mean/maximum vertical displacement for each individual segment and system, taken that they potentially ruptured independently, and finally for the entire Suasselkä PGF complex. For the entire complex rupturing in a single event, the observed displacement and length of the complex yields a moment magnitude estimate of $M_{\mathrm{w}} \approx 6.7-8.1$. However, based on geomorphological and sedimentological evidence, we believe that this is a conservative estimate of the moment magnitude of the paleoearthquake. If isolated PGF systems are considered to have ruptured individually, the moment magnitudes estimated based on surface rupture lengths range from $M_{\mathrm{w}} \approx 5.5-6.7$, and based on mean and maximum cumulative displacement values, the estimated values range from $M_{\mathrm{w}} \approx 6.2-7.3$ and $M_{\mathrm{w}} \approx 6.7-8.0$, respectively. As we cannot with the available data distinguish the exact number of events, the age of events or which segments potentially ruptured at the same time, we conclude that the events that took place in the complex ranged in moment magnitude from c. $M_{\mathrm{w}} \approx 5.5$ to 8.1 , the $M_{\mathrm{w}} \approx 8.1$ estimate representing conservative upper bound for the maximum moment magnitude.
\end{abstract}

Keywords LiDAR $\cdot$ Postglacial fault $\cdot$ Earthquake $\cdot$ Moment magnitude $\cdot$ Suasselkä $\cdot$ Finland

Electronic supplementary material The online version of this article (https://doi.org/10.1007/s00531-019-01695-w) contains supplementary material, which is available to authorized users.

Antti E. K. Ojala

antti.ojala@gtk.fi

1 Geological Survey of Finland, P.O. Box 96, 02151 Espoo, Finland

2 Geological Survey of Finland, P.O. Box 77, 96101 Rovaniemi, Finland

\section{Introduction}

Intraplate fault scarps that cross-cut glacial sediments, often referred to as postglacial faults (PGFs), are distinctive features in northern Fennoscandia (e.g., Lagerbäck and Sundh 2008; Olesen et al. 2004, 2013; Lund et al. 2017). Their existence indicates that the Fennoscandian Shield has experienced high-magnitude $\left(M_{\mathrm{w}} \approx 6.5-8.2\right)$ postglacial earthquakes attributable to the release of lithospheric stresses (Arvidsson 1996; Wu et al. 1999; Lund et al. 2009), 
which were much larger than those recorded in historical and instrumental times (e.g., Ahjos and Uski 1992). To our present best knowledge, all the known PGFs in the Fennoscandian Shield represent the reactivation of older fault zones, generally strike in a SW-NE direction and appear in areas that are also seismically active in the present-day lithospheric stress regime (e.g., Lagerbäck 1990; Olesen et al. 1992, 2013; Uski et al. 2003; Munier and Fenton 2004; Lindblom et al. 2015).

The availability of LiDAR (light detection and ranging) digital elevation models (DEMs) has increased understanding of the distribution and characteristics of PGFs in Fennoscandia (Smith et al. 2014; Sutinen et al. 2014a; Berglund and Dahlström 2015; Mikko et al. 2015; Palmu et al. 2015; Ojala et al. 2017). One of the facts better understood nowadays is that PGF zones are often composed of scattered, sometimes parallel segments that comprise longer PGF systems and form extensive PGF complexes (e.g., Ojala et al. 2017). While LiDAR data can be used to analyse PGF terrain surface structures and geometry and estimate potential earthquake moment magnitudes (e.g., Wells and Coppersmith 1994), there is a need for stratigraphic evidence that could be used to constrain the timing of fault instability and to investigate whether a PGF was formed in a single or in several subsequent ruptures. In the present study, we examine the Suasselkä PGF system in NW Finnish Lapland by describing the sediment stratigraphy and fault ramp displacement characteristics in trenched sections at two sites: Suaspalo and Retu. The stratigraphic observations are then combined with LiDAR topographic data to provide the depositional and faulting instability history of the area. This paper seeks to answer whether the faulting took place in one or several events and when they occurred.

\section{Geological background}

The Suaspalo and Retu fault scarps are part of the larger and Suasselkä PGF system, which strikes in a SW-NE direction, is composed of 17 fault segments and has a total length of $19 \mathrm{~km}$ (Fig. 1). Further southwest, the Suasselkä PGF system is connected with the Suasoja, Nilimaa and Sirkka PGF systems together forming the 72-km-long Suasselkä PGF complex (Fig. 2) (Palmu et al. 2015). The Suasselkä PGF complex runs almost parallel to the Isovaara-Riikonkumpu PGF complex, which is located 10 to $20 \mathrm{~km} \mathrm{SE}$ of it (Sutinen et al. 2014b; Ojala et al. 2017). While the NW block is the upthrown side of the Isovaara-Riikonkumpu PGF complex, the SE side is upthrown in the Suasselkä PGF complex. The presently studied fault scarps at the Suapalo and Retu sites are located in the NE part of the Suasselkä complex (Figs. 2, 3). At the Suaspalo site, the fault ramp is composed of two parallel fault zones that have a scattered appearance and several partially overlapping segments. The Suaspalo fault segment has a length of about $1 \mathrm{~km}$, a mean displacement of $0.8 \mathrm{~m}$, a maximum displacement of $1.6 \mathrm{~m}$ and disappears below Lake Suasjärvi (Fig. 3). Lake Suasjärvi drains towards the SE and was not dammed by faulting. The Retu segment is more linear than the Suaspalo segment, has a length of $5.5 \mathrm{~km}$, a mean displacement of $1.1 \mathrm{~m}$ and a maximum displacement of $2.7 \mathrm{~m}$ (Fig. 3).

The Suaspalo and Retu fault segments are reverse faults located within a unit of volcanic rocks intruded later by granodiorites (Fig. 1). On a larger scale, the entire Suasselkä PGF system is located in an extensive fault zone that has been interpreted based on apparent sinistral offsets of lithological units and clear discontinuities and minima observed on the airborne magnetic map (Fig. 2) (https://hakku.gtk.fi). It is notable that the fault zone interpreted from the magnetic data can be traced for at least $60 \mathrm{~km}$ further NE than has been identified as fault ramps from LiDAR data. This discrepancy is due to the fact that no LiDAR data are available NE of the current extent of the Suasselkä PGF system. The scarps of the Suasselkä fault system are partly concordant with bedrock lithological units and often follow the contact between mafic volcanic rocks and volcanic tuffs, indicating lithological control for the formation of the fault.

The Quaternary geology of the area is characterized by Weichselian and pre-Weichselian glacial stratigraphy with a generally low rate of glacial erosion and relatively complex ice-flow patterns during the most recent glacial stages (e.g., Kujansuu 1967; Hirvas 1991; Sutinen 1992; Salonen et al. 2014). Deglaciation of the area took place during the Early Holocene c. 11,300 cal BP, although it is likely that dead ice remained in topographic lows between fells for centuries. Lateral drainage channels, ancient shorelines and spillways of short-lived proglacial ice lakes are typical geomorphological characteristics in the area (Fig. 3). Glacial sediments, comprising diamicton and sand deposits, are partially overlain by postglacial sediments (clay, gyttja, peat). In some sections, traces of the Suasselkä PGF system are lacking, because they are buried under postglacial sediments that may post- or predate the last movements, but they are thick enough to absorb and/or mask the bedrock fault ramps. The Vänköselkä landslide, located about $10 \mathrm{~km} \mathrm{SE}$ of the Retu site (Fig. 2), is the only landslide discovered within $30 \mathrm{~km}$ of the present study areas (Ojala et al. 2018, 2019). Landslides are common farther SW of the study sites, in the vicinity of the Sirkka PGF system and Isovaara-Riikonkumpu PGF complex, where topographical relief is higher.

\section{Methods}

The Suaspalo and Retu sites were studied with ground penetrating radar (GPR) and by trenching. Altogether, 13 GPR survey lines of $120-500-\mathrm{m}$ in length were collected across 


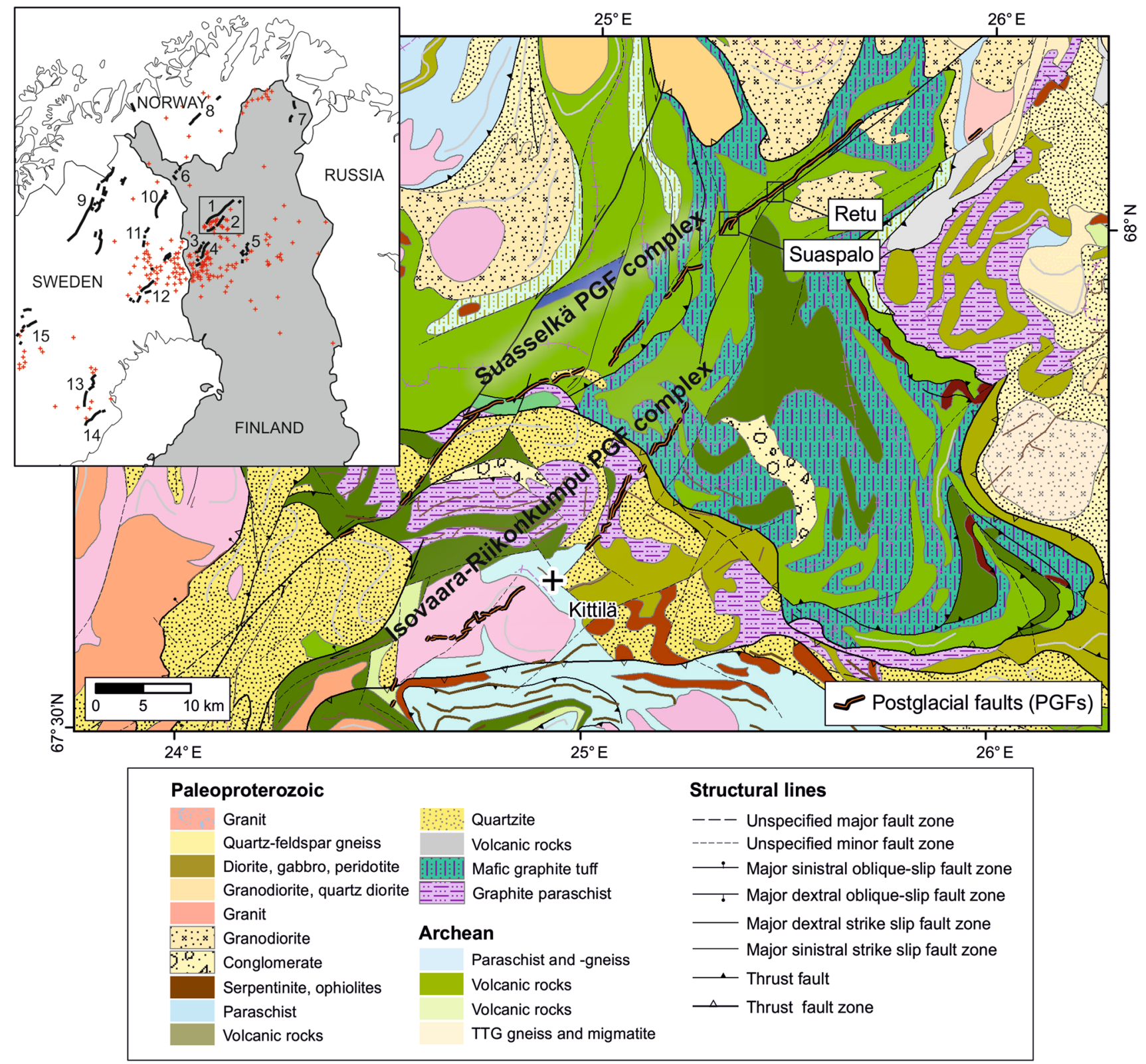

Fig. 1 Map showing the location of the studied Suasselkä PGF complex, bedrock characteristics in the area of the Suasselkä and Isovaara-Riikonkumpu PGF complexes, and other known postglacial faults in northern Fennoscandia. Numbers given in the index map refer to (1) Suasselkä, (2) Isovaara-Riikonkumpu, (3) VenejärviJauhojärvi, (4) Pasmajärvi, (5) Vaalajärvi, (6) Palojärvi, (7) Sevetti,
(8) Stuoragurra, (9) Pärvie, (10) Lainio-Suijavaara, (11) Merasjärv, (12) Lansjärv, (13) Röjnoret, (14) Burträsk and (15) Sorsele, and red crosses are landslides (see, e.g., Lagerbäck 1990; Olesen et al. 2004, 2013; Lagerbäck and Sundh 2008; Mikko et al. 2015; Sutinen et al. 2014a, b; Palmu et al. 2015; Ojala et al. 2017)

Trenches of $60 \mathrm{~m}$ and $70 \mathrm{~m}$ in length and 5-6 $\mathrm{m}$ in width were excavated at the Suaspalo and Retu sites, respectively, which were orientated perpendicularly to the fault ramps. The excavated trench at the Suaspalo site also intersects another subsidiary PGF segment on the NW side (Fig. 3). Vertical sections of the trenches were photographed and logged for lithostratigraphy and sediment structural characteristics. Measurements of till macrofabric orientation at the Ojala et al. 2017). 


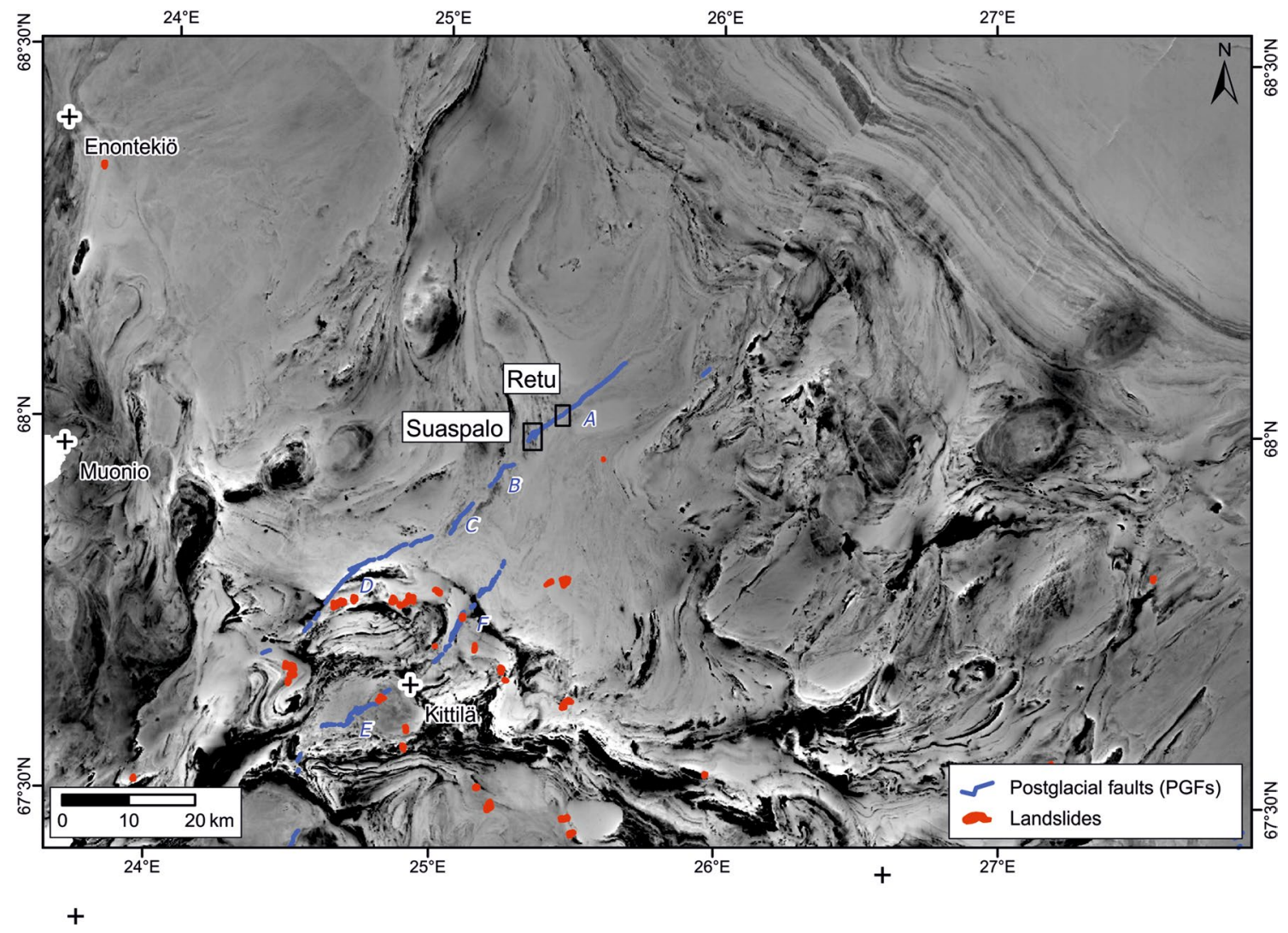

Fig. 2 Map of airborne magnetic anomalies in the area of the Suasselkä and Isovaara-Riikonkumpu PGF complexes (๔ GTK). Grey scale values indicate absolute magnetic anomalies that are mainly of lithospheric origin and reflect regional bedrock and fracture zone characteristics. The Suasselkä PGF complex is composed of the Suas-

Suaspalo site were conducted in seven locations along the trench by the traditional method of selecting and measuring the fabric element of random clasts within the matrix. The fabric orientation at the Retu site is based on the plunge and orientation of till cobbles across the fault.

In addition, selected measurements of macrofabric orientation at the Suaspalo site were duplicated using c. 10-cm-long plastic liners ( $5 \mathrm{~cm}$ in diameter) that were pushed into a vertical section of the trench wall, carefully removed and capped, and then analysed with computed X-ray tomography using a GE phoenix vltomelx s with a $400 \times 400 \mathrm{~mm}^{2} 4$ MPix detector. The orientation of cylinder sample tubes was determined with a compass-clinometer prior to sample removal. The aim of the $\mathrm{X}$-ray tomography measurements was to test the capability of the instrument in documenting till macrofabric orientation and sediment structures using discrete samples and on different grain-size assemblages. The settings used in X-ray tomography for each sample are presented in Table 1. The settings for T1 and $\mathrm{T} 8$ were different, because the capabilities of the system were tested by trying a coarser resolution (T1) or a faster scan time using the fastlscan module (T8). Results from these scans selkä (a), Suasoja (b), Nilimaa (c) and Sirkka (d) PGF systems, and the studied Suaspalo and Retu PGF segments are located in the NE part of the complex. The Isovaara (e), Riikonkumpu (f) and PGF systems form the Isovaara-Riikonkumpu PGF complex (Ojala et al. 2017)

were comparable with the others but required more extensive analysis. For orientation analysis, the grains within the till samples were segmented using a marker-based watershed and then separated using the "Separate objects" tool in PerGeos, the software used here for data analysis and visualization. The orientation angles were then individually analysed for each separated grain.

Fine-grained material from clastic dikes in the faults was analysed using X-ray diffraction with a Bruker D8 Discover diffractometer over the range $2-70^{\circ} 2 \Theta \mathrm{CuK} \alpha$. Adjustments of the generator were $40 \mathrm{kV} / 40 \mathrm{~mA}$, the step size was $0.02^{\circ}$ and the measurement time $0.2 \mathrm{~s}$. The Bruker software EVA was used to identify the phases according to the ICDD (International Centre for Diffraction Data) mineral database PDF-4 Minerals 2015. 


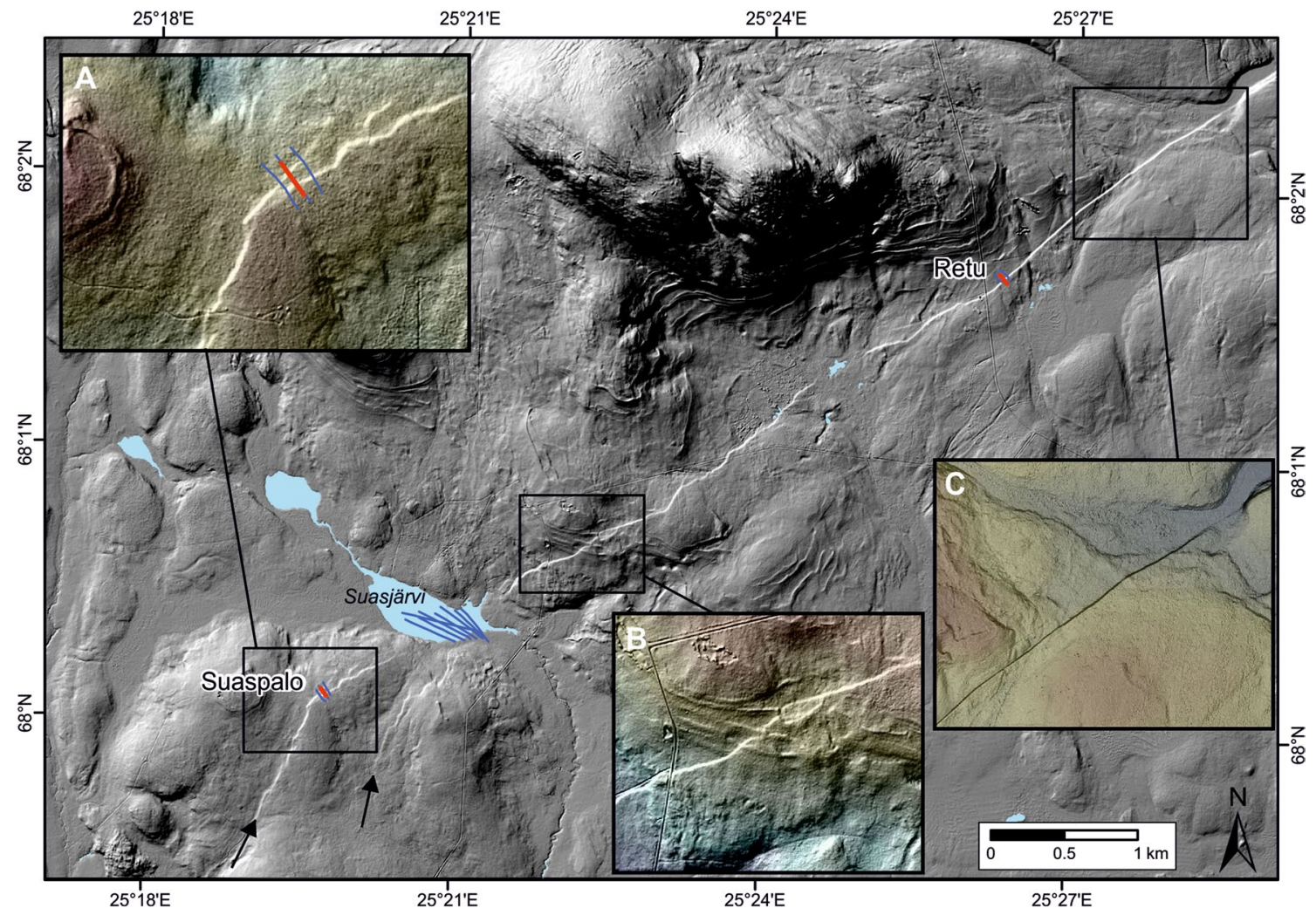

Fig. 3 LiDAR-based digital elevation model of the Suasselkä PGF complex at the Suaspalo and Retu study sites. Colour inset images highlight the characteristics of the main and subsidiary fault segments at the Suaspalo study site (a), several lateral drainage channels that are cross-cut by the fault NE of Lake Suasjärvi (b) and a proglacial

Table 1 Settings applied for different samples in X-ray tomography

\begin{tabular}{lllll}
\hline Sample & T1 & T2, T3, T4, T7 & T8 & T9 \\
\hline Accelerating voltage (kV) & 100 & 100 & 100 & 100 \\
Current (mA) & 420 & 270 & 270 & 270 \\
Power (W) & 42 & 27 & 27 & 27 \\
Steps (per 360 $\left.{ }^{\circ}\right)$ & 2100 & 2500 & 1799 & 2500 \\
Exposure (ms) & 333 & 500 & 500 & 500 \\
Averaging & 3 & 3 & 1 & 3 \\
Skip & 1 & 1 & 0 & 1 \\
Total scan time (min) & 47 & 83 & 15 & 83 \\
Resolution (mm) & 42.22 & 28.09 & 28.09 & 27.83 \\
\hline
\end{tabular}

At each angle, the detector waited for the number of exposure times determined in "Skip" and then captured the number of images determined in "averaging" and averaged these for the final projection. All the samples were scanned with a $0.1-\mathrm{mm}$ copper filter ice lake spillway that is cross-cut by the fault NE of the Retu study site (c). Locations of the Suaspalo and Retu trenches across the fault scarp are marked with red lines, while blue lines indicate the locations of ground penetrating radar (GPR) profiles

\section{Results and interpretation}

\section{The Suaspalo site}

For most of its length, the PGF is visible in till sediments, and as evidenced by GPR profiles, it passes beneath Lake Suasjärvi northeast of the Suaspalo study site (Fig. 4). The GPR profiles exhibit gently dipping sedimentary strata extending $10-15 \mathrm{~m}$ across the scarp location with an approximately 2-m-high offset on the till surface. Reflectors from till can be similarly traced on the hanging and footwall sides of the fault and they do not show any sharp sediment-cutting features or folding characteristics. The rupture zone is filled with postglacial lacustrine sediments (clay gyttja and gyttja) that exhibit horizontal structures without any disturbances. Regarding the location of the rupture below Lake Suasjärvi, we cannot verify which segment of the fault is connected to on the south side of the lake. However, on the NE side of the lake, the direction is clearly towards the fault segment detected in LiDAR data.

The main and subsidiary NW fault scarps are distinct in GPR profiles and in sediment stratigraphy at the Suaspalo 


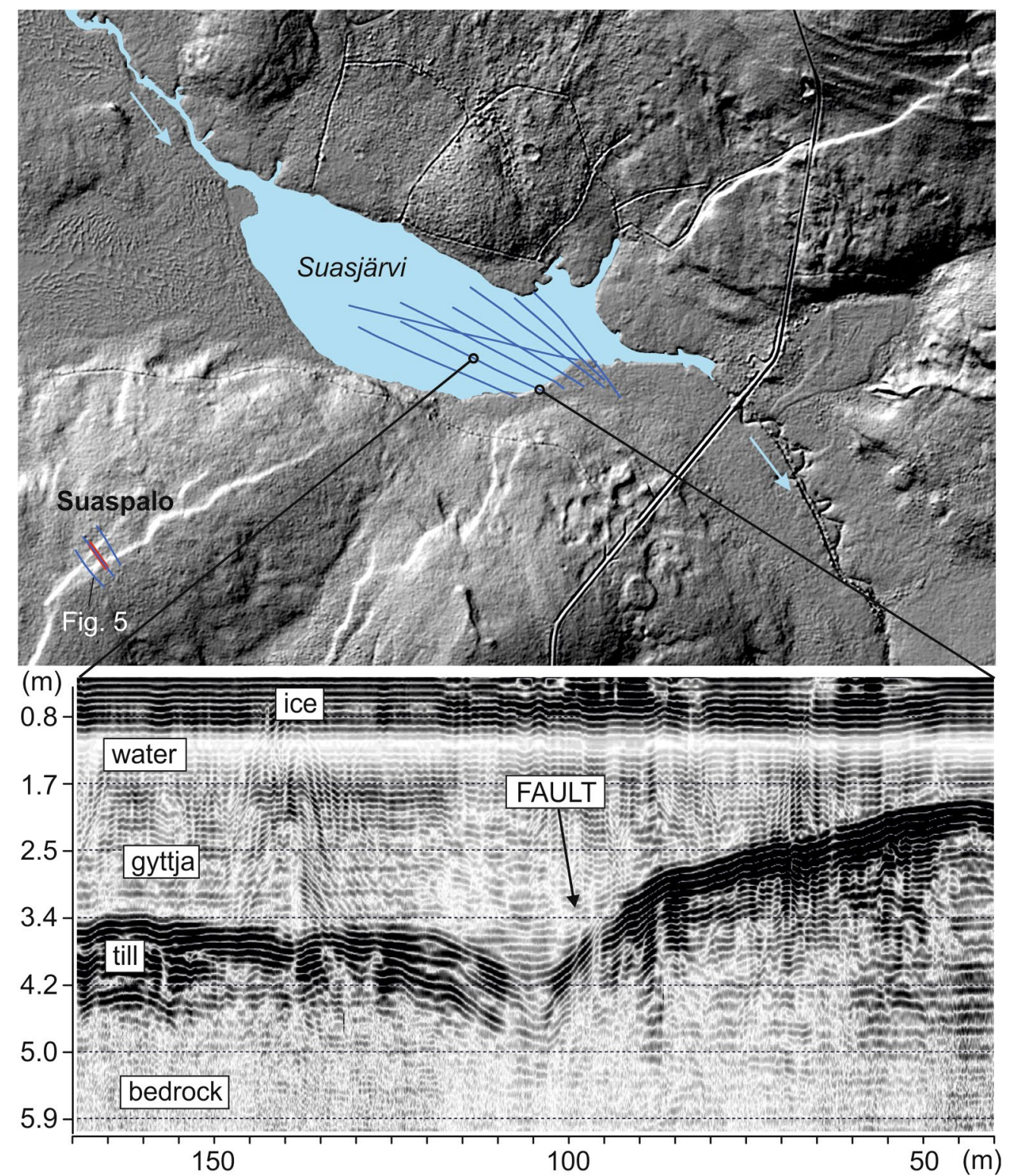

Fig. 4 Interpretation of a ground penetrating radar (GPR) profile across the Suaselkä fault scarp beneath Lake Suasjärvi in Kittilä. The location of the Suaspalo trench is marked with a red line, while blue lines indicate the locations of ground penetrating radar (GPR) profile lines

study site (Figs. 5, 6). The GPR profiles show prominent stratigraphic units and continuous reflectors of gently dipping strata for the main fault, whereas across the NW fault the reflectors are more chaotic and partially disrupt facies continuity. The chaotic facies is interpreted as disorganized or bended material, which destroys the smooth continuity. Away from the faults, the sediment facies reflected in the profile are generally horizontal and related to the stratigraphy of superficial deposits. These observations are in line with stratigraphic studies, as presented below. The height differences between the hanging and footwall in the sediment units in GRP profiles at the fault scarps are of the same magnitude (about $1 \mathrm{~m}$ ) as those seen in the LiDAR DEM data.

The stratigraphy in the trench indicates that the glacial sediments at the Suaspalo site are composed of two diamicton units (units 1 and 2) that lie on weathered bedrock (unit 3) and represent glacial till from the Weichselian glaciation (Fig. 6). Unit 1 is the thickest unit throughout the excavated trench and varies between 2 and $4 \mathrm{~m}$ in thickness. It is composed of massive brownish matrix-supported diamicton characterized by a low content of angular to sub-angular cobble- to pebble-sized clasts. The matrix is sandy. The lower contact of unit 1 to unit 2 is mostly 
Fig. 5 Ground penetrating radar (GPR) profile across the Suasselkä fault scarp at the Suaspalo trenching site (see Fig. 4 for the GPR profile location)

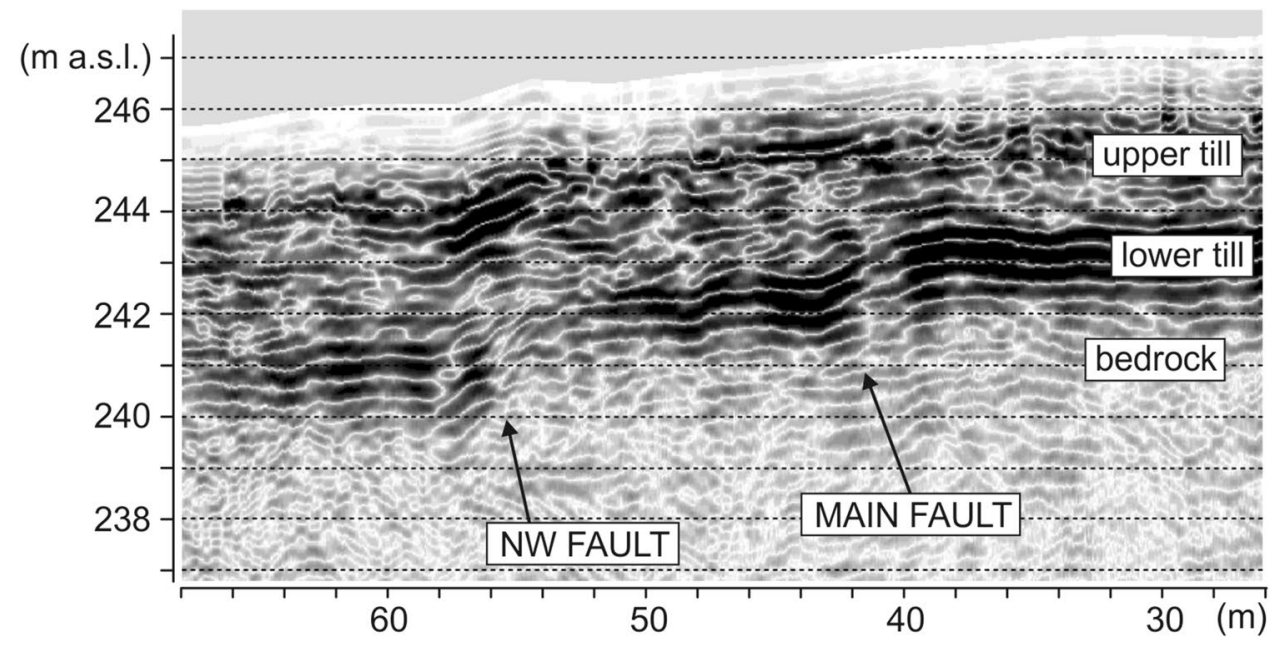

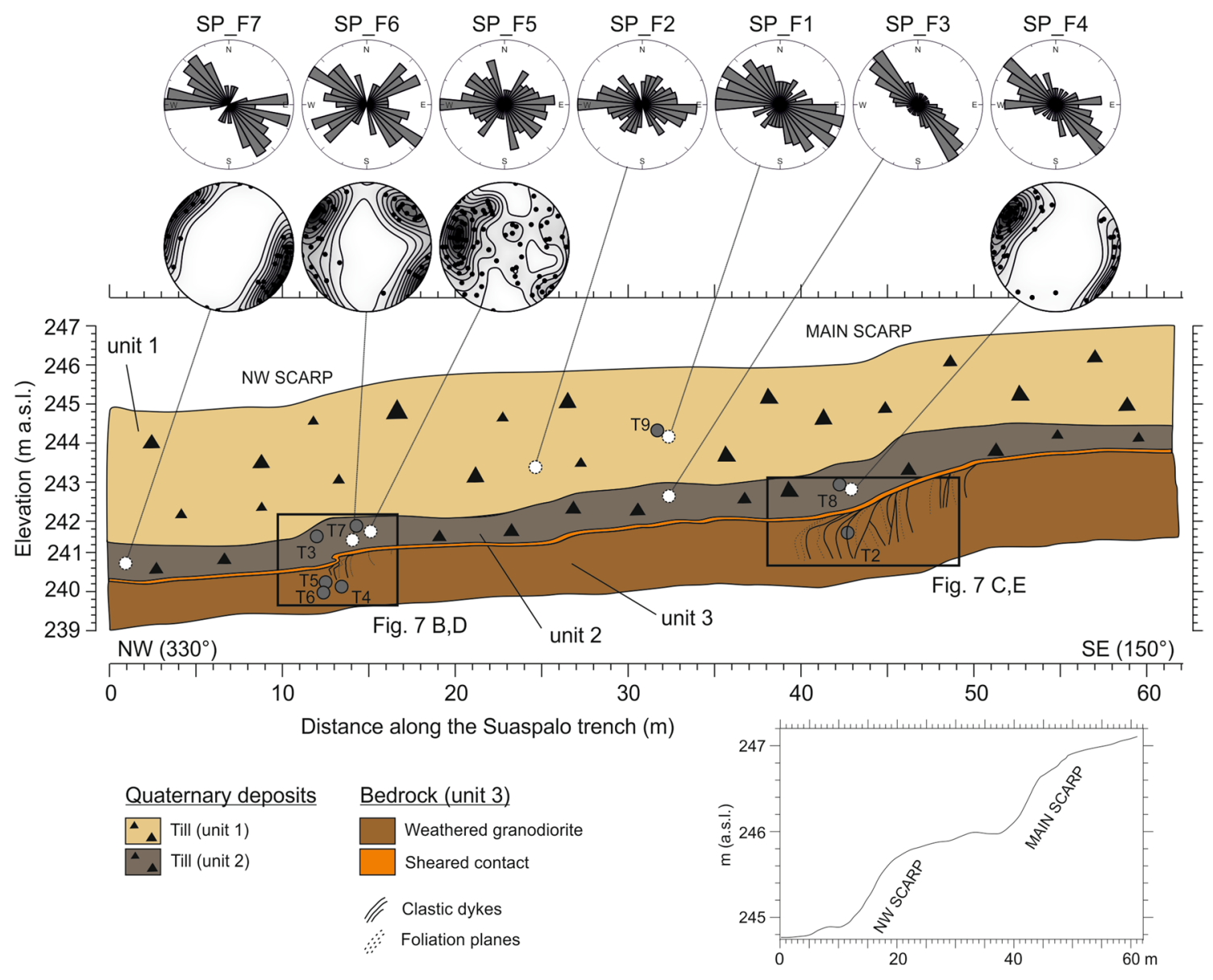

Fig. 6 Profile information, macro-fabric directions and sediment lithostratigraphical units and characteristics of vertical sections in the Suaspalo trench (see Figs. 3, 4 for the trench location). The macrofabric directions of tomography samples T2 and T7 are presented in Fig. 8

gradational and the top-most $40-50 \mathrm{~cm}$ of unit 1 indicate ongoing soil processes in weakly fissile diamicton. The lower diamicton unit 2 is also recognized throughout the trench as a rather evenly thick (c. $1 \mathrm{~m}$ ) layer composed of dark greyish to brownish glacial till. Unit 2 displays faint lamella structures with weak stratification and is mostly composed of a matrix of silt to fine sand. 
The directional elements of the Suaspalo till units (units 1 and 2) are presented in Fig. 6. The direction towards the ENE is weakly developed in the fabrics of the upper till (unit 1), which, together with the stratigraphic position, we associate with the Late Weischselian till reported by Kujansuu (1967), the Nordkalott Project (1986) and Sutinen (1992). Salonen et al. (2014) described the same upper till in the Hannukainen area some $60 \mathrm{~km} \mathrm{SW}$ of the Suaspalo study site, although their fabric direction was slightly more towards the ENE, in accordance with the Naakenavaara section by Hirvas (1991). It is typical that the fabric of the uppermost lodgement till in central Finnish Lapland is often poorly orientated and that the ice-flow direction varies considerably, even within a limited area, but generally indicates glacier advancement towards the east and/or NE (Sutinen 1992; Salonen et al. 2014). The direction of the lower till (unit 2) in the Suaspalo section is well developed and towards the SE, as indicated by data from SP_F3 and SP_F4 (Fig. 6). It is connected with the Middle Weichselian till as described by Nordkalott Project (1986) and Sutinen (1992), although Salonen et al. (2014) described two Middle Weichselian till units with slightly variable fabric directions, the lower one towards the SE and the upper one towards the south, at the Hannukainen site.

Overall, the characteristics and directional elements of the Suaspalo site suggest that glacial stratigraphy is composed of till units that represent Late Weichselian (unit 1) and Middle Weichselian ages (unit 2).

The lowermost unit (unit 3) in the Suapalo stratigraphy is comprised of reddish weathered granodiorite with a distinctively sheared upper contact to overlying diamicton throughout the excavated 60-m-long trench (Fig. 6). The
Fig. 7 Photographs and sketches showing the characteristics of the NW $(\mathrm{B}, \mathrm{D})$ and the main $(C, E)$ scarps at the Suaspalo trenching site. The upthrown blocks are on the right side (southeastern side) and a description of the lithological units is given in Fig. 6

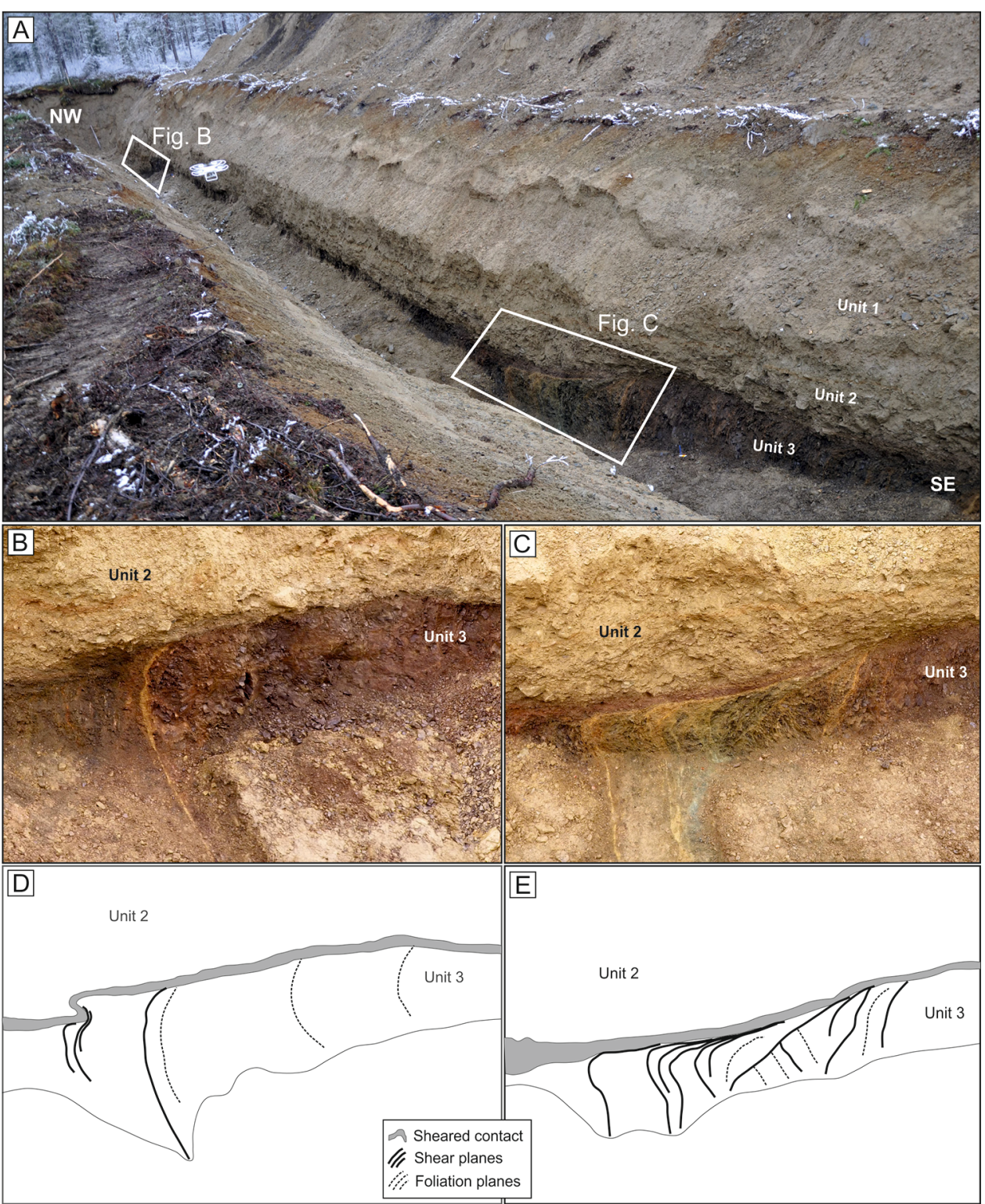


sheared layer is about $10-15 \mathrm{~cm}$ thick. Old fault zones were observed in the bedrock (unit 3 ) at the locations of the fault scarps seen in the LiDAR data (Figs. 3, 7). These zones are strongly fractured and contain distinct clastic dykes that are filled with yellowish clayey sediments containing sub-angular to edge-rounded granules and very coarse sand (Figs. 7, 8 ). The fine-grained material in these dykes is composed of swelling mixed clay particles, mainly with an association of smectite and vermiculite. In addition, samples also contain a minor proportion of kaolinite and chlorite, as well as crystalline phases of K-feldspars, quartz, anatase, christobalite and plagioclase. This type of mineralogy and geochemistry of the fine-grained fraction of till is typical for this area (Peuraniemi et al. 1997), which indicates that the material in bedrock fractures is derived from local superficial deposits. Downward infilling and squeezing of (liquefied) material into bedrock cracks was probably enhanced by the weight and movement of the overlying glacier (Larsen and Mangerud 1992). The till stratigraphy (units 1 and 2) and the distribution and appearance of the till dykes allow us to consider the relationship and timing between ice movement and faulting of the bedrock during Weichselian.

The NW fault consists of three distinct clastic dykes filled with till-derived material. The orientation of these dykes is c. $73^{\circ} / 130^{\circ}$ and they are thus quite vertical. The clastic dykes folded and sheared along the contact between the bedrock and lower till unit towards the SE during glacial advance. An important feature of the NW fault zone is that the sheared contact between the bedrock and lower till unit is folded, which indicates fault movement took place after the deposition of till unit 2 and the formation of the clastic dykes. The microfabric orientation of the particles in the clastic dykes (Fig. 8) has a high degree of isotropy and most of the particles are sub-vertical and aligned within the plane of the dyke. This is in contrast to the macrofabric of the lower till unit, which is more anisotropic and heterogeneous in orientation, although having a tendency towards weak maxima of the long particle axis striking in a $\mathrm{W}-\mathrm{E} / \mathrm{NW}-\mathrm{SE}$ orientation and having a gentle plunge. We consider this as evidence that as the till that was injected into the fractures in the bedrock, it was later deformed and the particles reoriented to their current orientation, with the long axis aligned along the plane of the dyke. In addition, the macrofabric orientation of SP_F6 and SP_F5 is clearly lost at the NW fault ramp when compared with the results for SP_F3, SP_F4, and SP_F7 at the main scarp, suggesting that pre-existing till was deformed during faulting. When combined with the fact that the offset of the bedrock between the footwall and hanging wall sides is c. $0.5 \mathrm{~m}$, which is less than detected from the LiDAR data $(1 \mathrm{~m})$, we infer that the NW scarp was formed in at least two separate slip events that pre- and postdate the deposition of the lower till (unit 2).

At the main SE fault scarp, the bedrock consists of c. 10 -m-wide damage zone with approximately 10 clayey clastic dykes up to $10 \mathrm{~cm}$ thick. The orientations of the dykes are sub-vertical and, in accordance with the NW fault, the dykes of the main fault scarp are folded and dragged along the contact between the bedrock and the lower till unit (unit 2). Importantly, in contrast to the NW scarp, the sheared contact between the lower till and weathered bedrock do
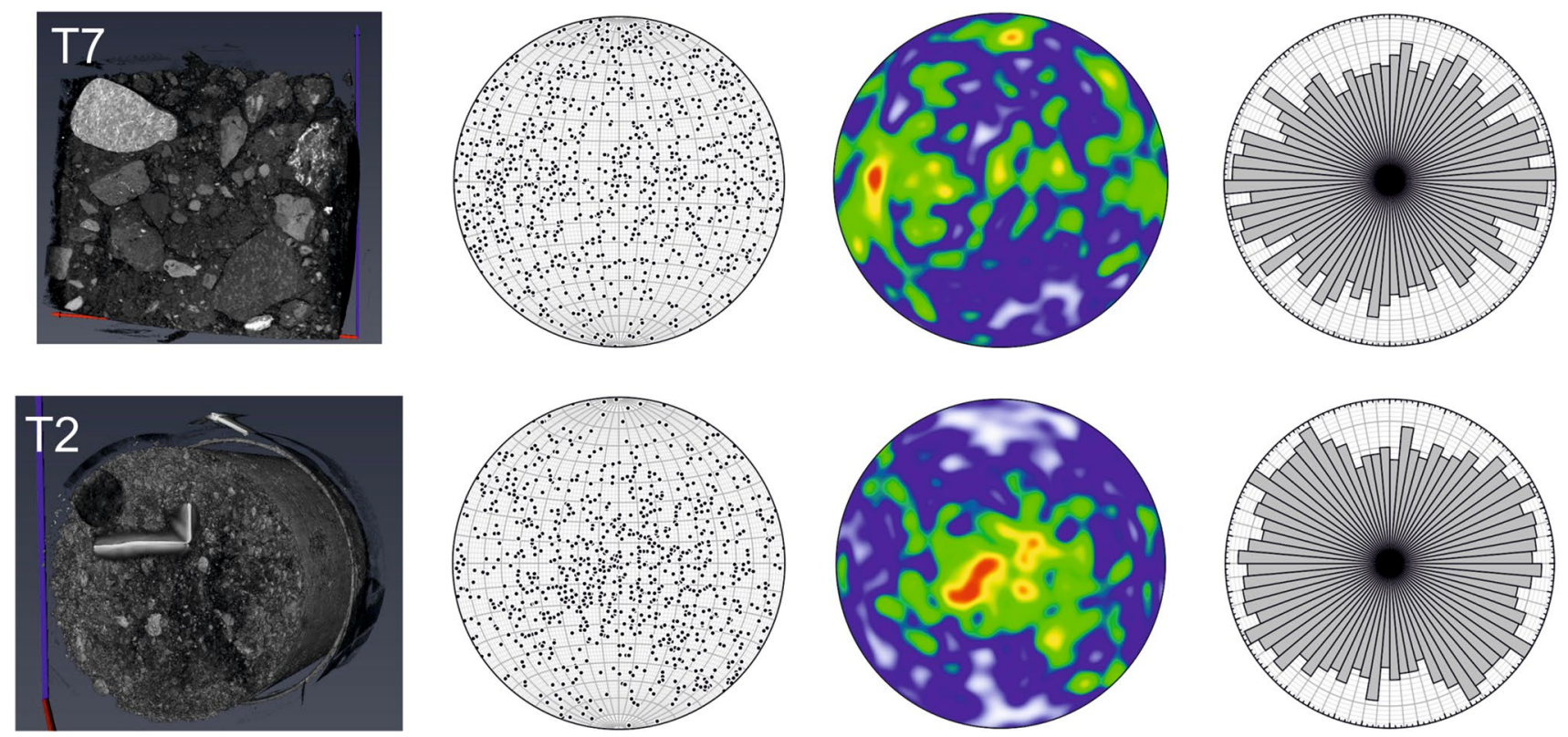

Fig. 8 Orientation of macro-fabrics in the lower till unit 2 (T7) and in the clastic dyke (T2) as revealed by computed X-ray tomography. Images on the left side represent the 3D tomographic cut planes of the samples. See Fig. 6 for sample locations 

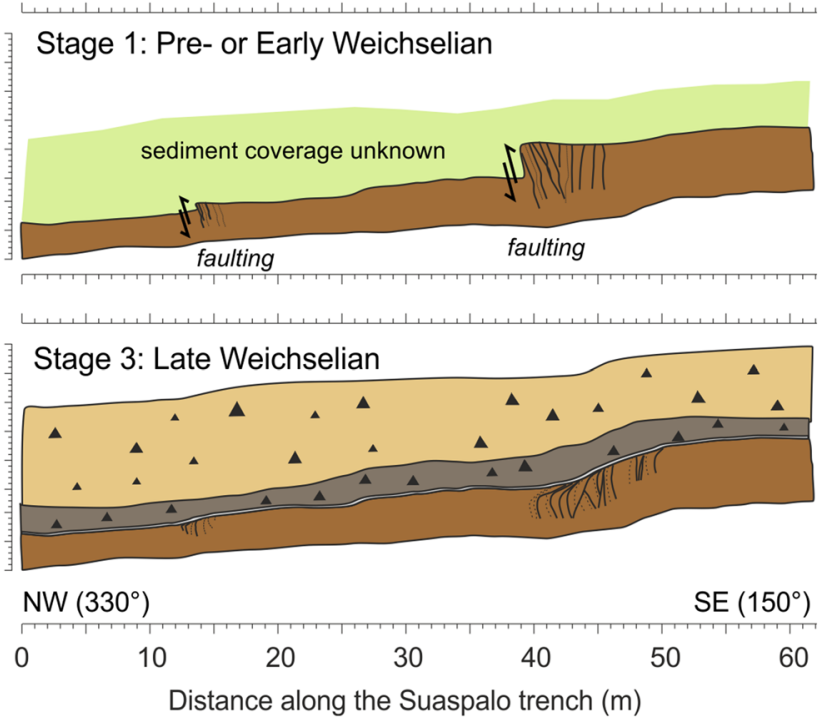
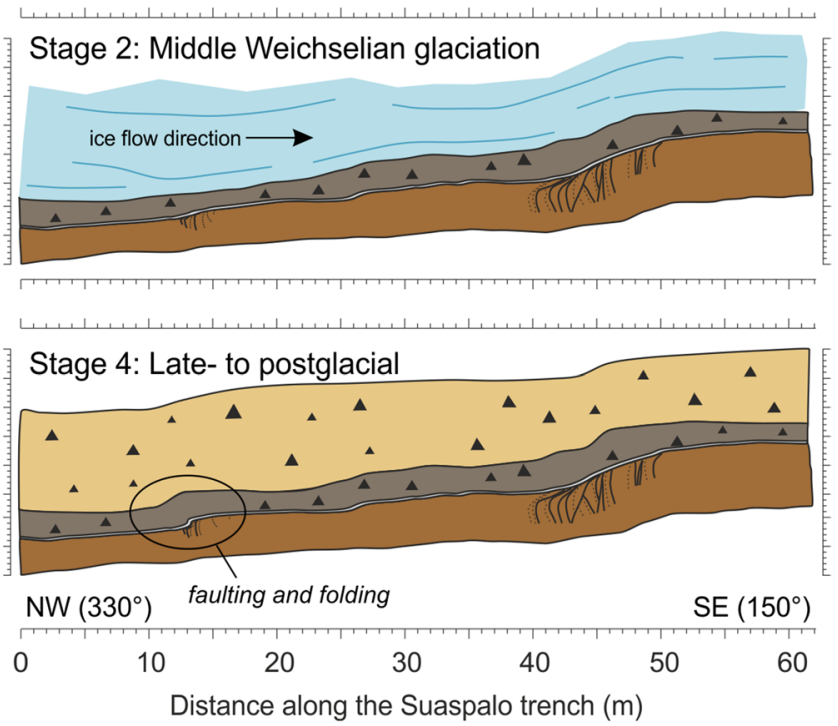

Fig. 9 Simplified model of the faulting, folding and deposition of different lithostratigraphical units during fault instability at the Suaspalo trenching site (see Fig. 6 for a description of lithostratigraphical units)

not shows any sign of folding or faulting at the main scarp that would post-date the deposition of the lower till (unit 2).

The inferred sequence of events for faulting and folding at the Suaspalo site is presented in Fig. 9. Fault scarp resulting from an earlier fault instability already existed in the bedrock in the pre-Weichselian stage 1. In the next stage (stage 2), which represents the advance of Fennoscandian Ice Sheet and deposition of the lower till (unit 1), the ice movement caused significant erosion of sediment coverage and bedrock, and degradation of the earlier fault scarps and formation of a continuous sheared layer of weathered bedrock along the contact. During this advance, weathered bedrock, clay-filled dykes and remnants of the fault scarp were dragged along the contact towards the ice-flow direction. We note that the sheared contact must be the results of ice movement rather than due to differential movements in the bedrock due to faulting as the sheared layered is continuous along the trench. If the shearing along the contact would have been a result of faulting, we would expect to see the sheared layer constrained only to the near proximity of the fault core. In the third stage (stage 3), deposition of the upper till (unit 1) took place during Late Weichselian. It was followed by a second slip event that took place only in the NW fault, resulting in the folding of the sheared layer (stage 4) (Figs. 5, 6, 7). The SE main fault does not show any sign of folding of the sheared layer or any offsets along it, which would be expected if the fault cores were activated and slipped at this second stage. We thus infer that only the NW fault was active during or after the Late Weichselian deglaciation. Combined, these observations indicate that multiple rupturing events can take place within 'postglacial fault complexes', and that the observed slip on the main SE fault scarp is older than the lower till and thus potentially dates to the Early or even pre-Weichselian period.

\section{The Retu site}

Four different lithostratigraphical units were described in the vertical section of the Retu trench (Fig. 10). The lowermost unit is primarily composed of weathered and highly fractured granite (unit 4), which is not indicated on the lithological bedrock map. An old and highly weathered and fractured mylonitic zone appears at the location of the scarp. Fractures in the mylonite are filled with yellowish clay-bearing clastic dykes, similar to those described at the Suaspalo site. The sediment structures indicate that the zone has reactivated along a pre-existing clay-bearing shear/fault zone and forms a distinct scarp that has an offset of c. $1 \mathrm{~m}$, with the SE side of the fault plane being upthrown. At the contact, the clayey dyke material has been partly dragged along the fault plane with a $77^{\circ} / 122^{\circ}$ orientation of the fault plane, thus indicating reverse movement of the fault in the latest stage of faulting.

The weathered bedrock is partly overlain by a layer of coarse-grained gravel (unit 3 ) with pebbles and cobbles and a general thickness of 0.5 to $1.3 \mathrm{~m}$. The gravel is mostly comprised of matrix-rich (sand) clast-supported material with an imbricated structure and traces of scour surfaces on the underlying bedrock. The unit is thickest at the bedrock fracture, indicating a filling type of appearance. We believe that the unit represents a water-transported fluvial spillway sedimentary environment, where gravel filled the bedrock fractures when the ice had melted back. The age of the deposit is unknown. 


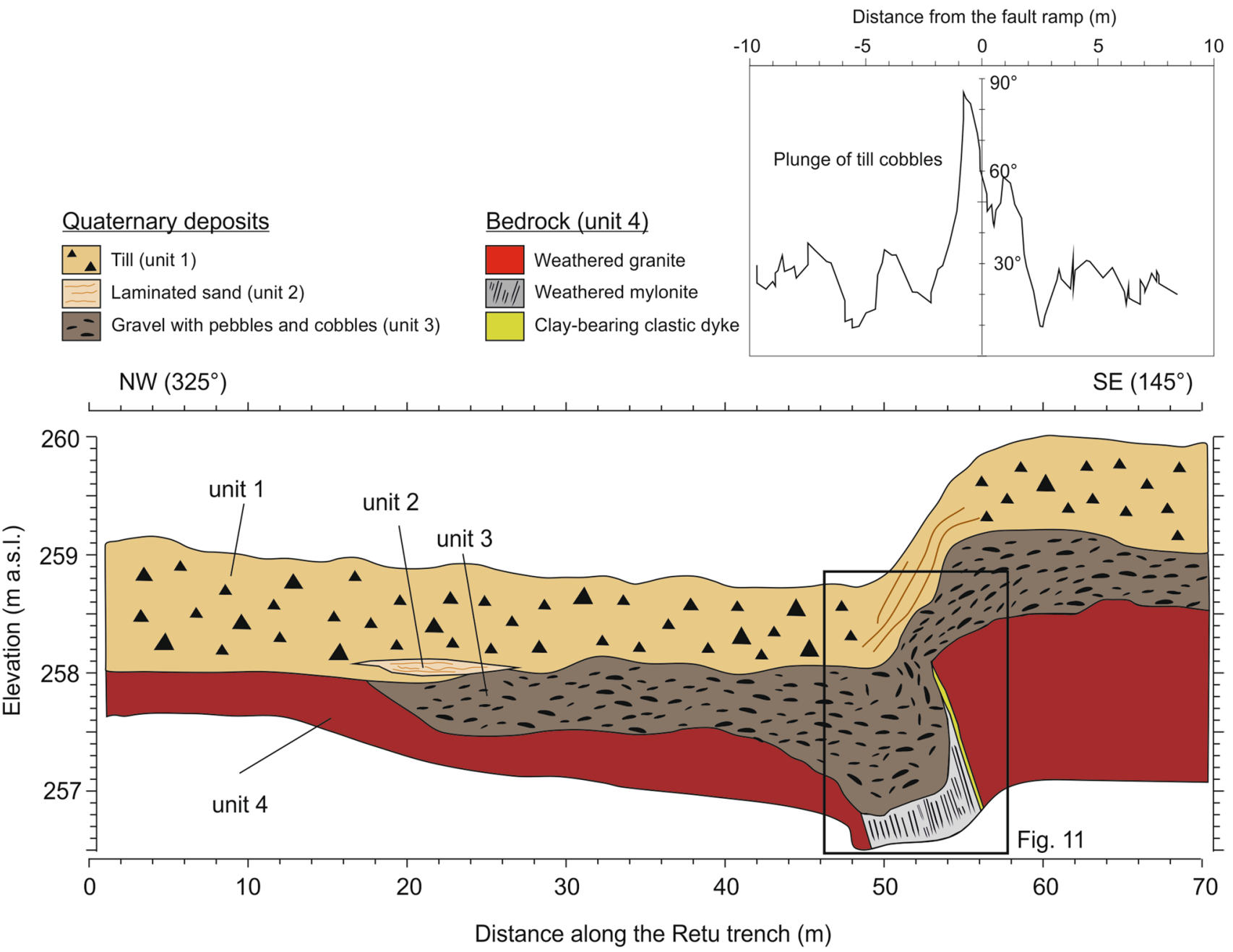

Fig. 10 Profile and plunge of cobbles at the Retu trenching site (Suasselkä PGF system), with sediment units and characteristics (see Fig. 3 for the trench location)

A unit of till (unit 1) with an average thickness of $1 \mathrm{~m}$ lies upon the gravel and weathered bedrock throughout the Retu trench wall. It is composed of loose, brownish-grey and matrix- to clast-supported diamicton characterized by a high content of angular to sub-angular cobble- to pebble-sized clasts. Unit 1 has no particularly distinctive features and either represents meltout till of the retreating glacier, and/or was significantly washed by meltwater during deglaciation. The matrix is sandy and the lower contact to unit 2 is mostly sharp. Within unit 1 , small pockets of laminated sand (unit 2) are occasionally observed.

What is important from the fault instability perspective is that both the gravel and till units are clearly offset and deformed at the fault ramp in the Retu trench (Fig. 11). The plunge of the cobbles in till unit 1 is progressively rotated from the more general horizontal to an almost vertical orientation when approaching the fault scarp (Fig. 10). The longest axes of cobbles in units 1 and 2 are almost vertical at the fault scarp and generally orientated concordant with the fault plane between $75^{\circ}$ and $80^{\circ}$ (Fig. 11). The sandy laminae on the slope of the scarp were interpreted to have been deposited after the faulting due to the collapse of material on the rim of the raised block. All this evidence indicates that the faulting must have occurred postglacially.

Based on the lithostratigraphic observations, we can infer a sequence of deposition and deformation events that took place at the Retu site before and during faulting (Fig. 12). In the first stage (stage 1), a distinct trough or depression existed at the location of the mylonite due to the weathering of the bedrock and repeated glacial erosion during the Late Pleistocene. In the next stage (stage 2), a gravel bed was deposited in the trough, and potentially during the deposition and flowing of water, the trough was further eroded and deepened. This was followed by the deposition of till and laminated sands (stage 3) and eventually the faulting event took place (stage 4), leading to the structures observed in 


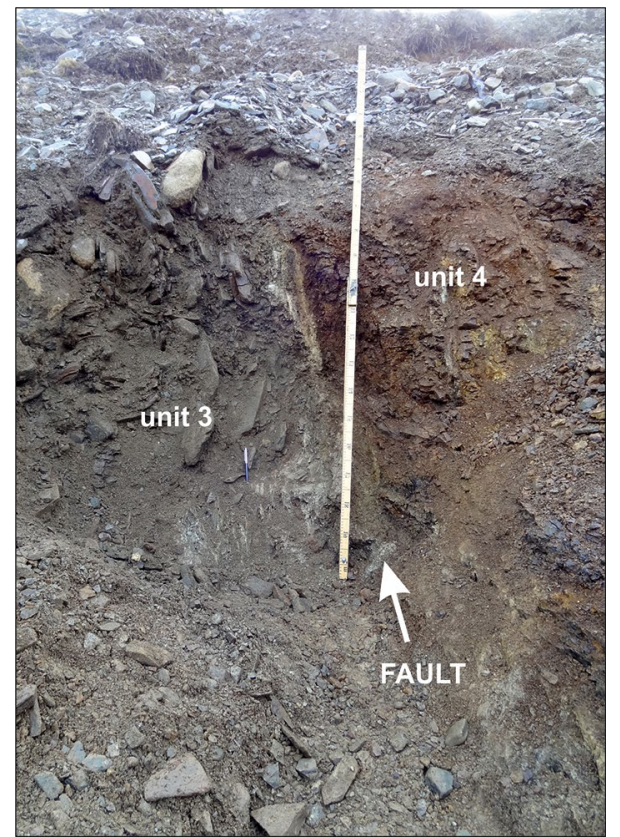

Fig. 11 The fractured and weathered edge of the hanging wall at the Retu trench wall (see Fig. 10 for the location). A pale yellowish clayey clastic dyke is seen in the fault zone between units 3 and 4

the trench today. The impact of fault displacement on different stratigraphic units is clearly demonstrated and dated to the postglacial period. From the structures observed in the trench, we cannot, however, conclude whether the scarp was formed in one or several slip events. Postglacial faulting nevertheless exploited an old and pre-existing zone of weakness, as is often seen in postglacial faults. In the case of the Retu site, the fault is, however, very steep, suggesting that the pre-existing zone must be very weak, as its orientation is highly incompatible with a thrust regime, which is often assumed to be the underlying stress state triggering postglacial faults.

\section{Discussion}

\section{Estimation of earthquake moment magnitudes}

With a lack of direct seismic monitoring data, the potential moment magnitudes $\left(M_{\mathrm{w}}\right)$ of palaeoseismic events can be estimated from scaling laws that link earthquake magnitudes to maximum cumulative surface displacement (MaxCSD) values, mean cumulative surface displacement (MeanCSD) values and surface rupture lengths (SRL), and which are based on observations from past instrumentally monitored events. In order to estimate the moment magnitudes for the Suasselkä PGF complex, we used scaling laws for reverse faults from stable continental regions (Leonard 2010; Moss and Ross 2011; Wells and Coppersmith 1994) and estimated what are the potential ranges of the moment magnitudes that the faults may have hosted. With the use of different scaling equations we are further able to assess potential uncertainties in the estimations. The Suasselkä PGF complex consists of a total of 37 isolated segments, which we have further grouped into a total of 4 systems, defined on the basis of
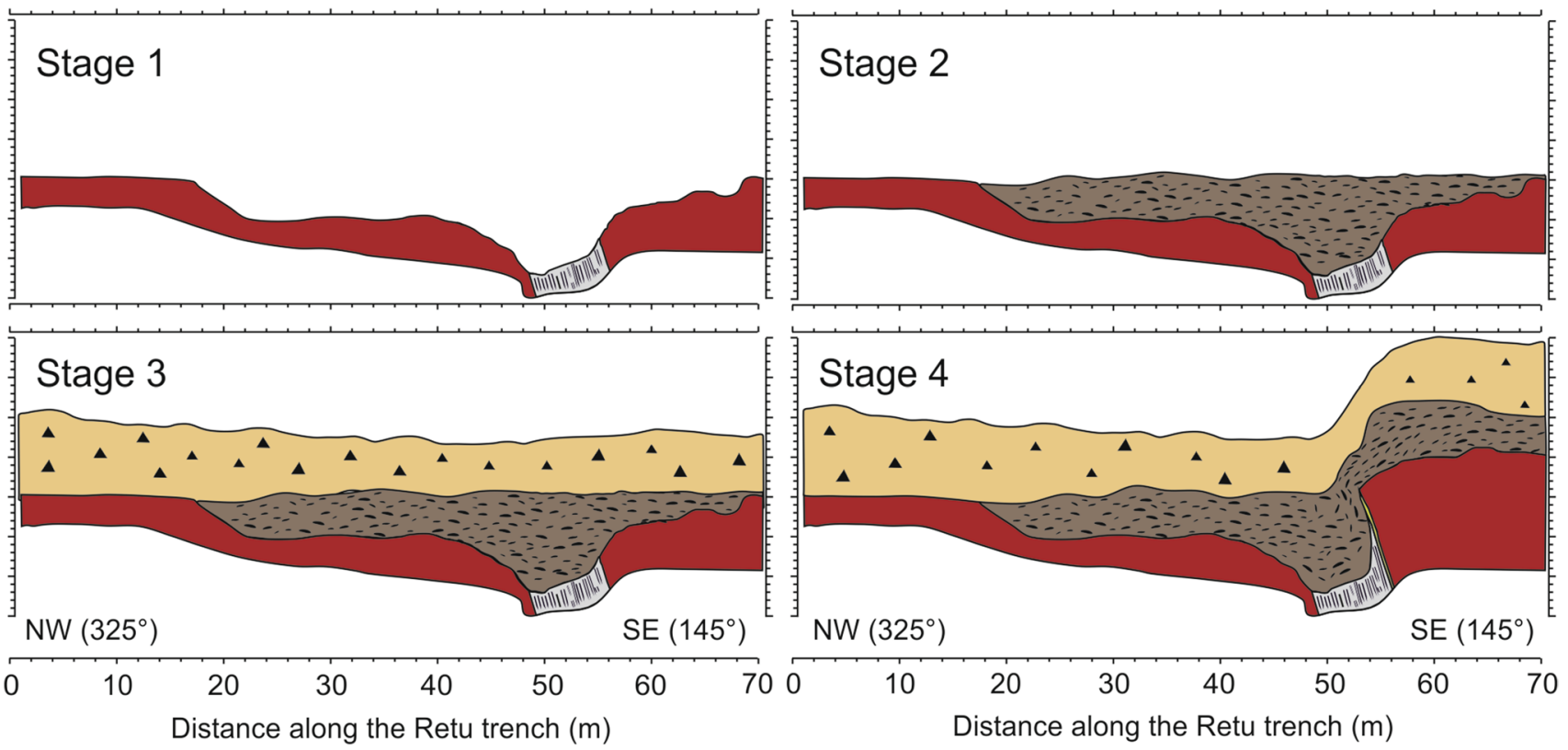

Fig. 12 Simplified model of the deposition and movement of different lithostratigraphical units during fault instability at the Retu trenching site. Note the sub-vertical orientation of clasts (cobbles) at the fault location in stage 4 (see Fig. 10 for a description of lithostratigraphical units) 
closely associated groups of segments and non-ruptured sections separating the groups (Fig. 2). The non-ruptured sections between the defined systems vary in length from 2.9 to $4.1 \mathrm{~km}$. Observations of the historical surface ruptures of earthquakes suggest that earthquakes rarely jump over distances of about $5 \mathrm{~km}$ between segments, and such distances are thus sufficient to stop earthquake ruptures (Wesnousky 2006, 2008). Thus, in our grouping of surface rupture segments, it is possible that each of the defined systems may have potentially ruptured during a single event, but in order to take into account uncertainties related to the timing and number of past events, we have analysed what the potential moment magnitudes would be if isolated segments and/or systems ruptured independently and, finally, what the magnitude would be if the entire Suasselkä PGF complex ruptured in a single event. These three different approaches are outlined below.

\section{Segment-based approach}

The regression functions used to estimate the moment magnitudes $\left(M_{\mathrm{w}}\right)$ with associated references, lengths and vertical displacements of individual segments, systems and complexes, as well as the computed moment magnitudes are given in the supplementary file (S1). We computed the moment magnitude estimations based on surface rupture lengths, mean and maximum vertical displacements and mean and maximum displacements based on estimated dips of $70^{\circ}$ and $80^{\circ}$, corresponding to the dip fault ranges observed in the trenches. Assuming that the segments ruptured individually, the moment magnitudes estimated based on surface rupture lengths range from $M_{\mathrm{w}}$ $\approx 3.0-5.8$, while the estimates based on mean and maximum cumulative displacement yield values ranging from $M_{\mathrm{w}} \approx 2.9-8.4$ and $M_{\mathrm{w}} \approx 4.7-8.0$, respectively (Fig. 13). If the estimated dips of the faults are accounted for, the mean displacement for the dip of $70^{\circ}$ gives moment magnitude estimations of $M_{\mathrm{w}} \approx 3.0-8.5$, and for the dip of $80^{\circ} M_{\mathrm{w}} \approx 2.9-8.4$. For maximum displacement values, the moment magnitudes range between $M_{\mathrm{w}} \approx 4.7-8.1$ and $M_{\mathrm{w}}$ $\approx 4.7-8.0$, respectively.

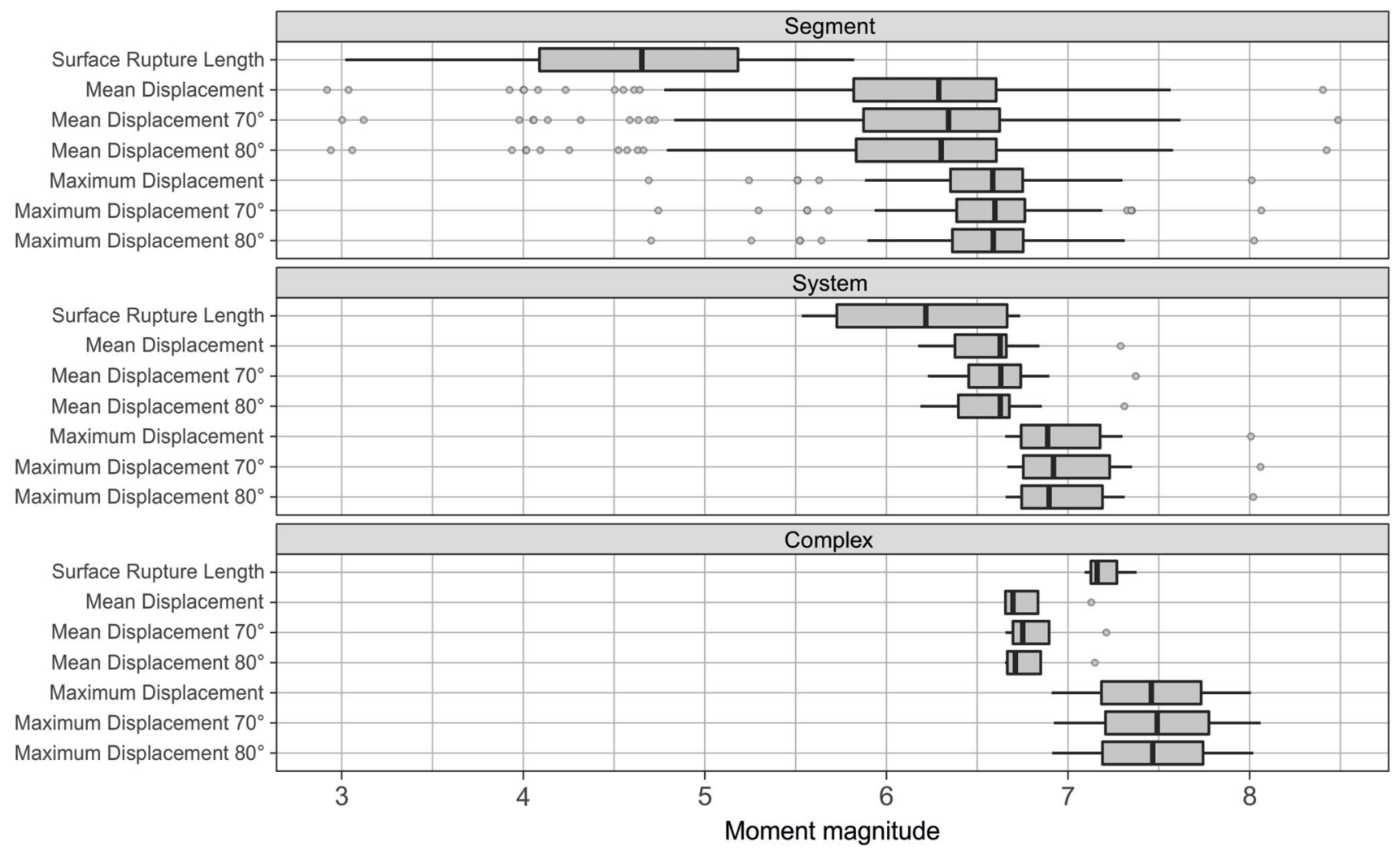

Fig. 13 Paleoseismic moment magnitude $\left(M_{\mathrm{w}}\right)$ calculation for the segments, systems, and for the entire Suasselkä PGF complex based on the length of the surface rupture (MSRL) and the cumulative surface rupture displacement (MeanCSD, MaxCSD) with vertical dip and dip values of $70^{\circ}$ and $80^{\circ}$. Quartiles $(0.25-0.75)$ are provided with shaded grey boxes (Wells and Coppersmith 1994; Leonard 2010; Moss and Ross 2011). The potential outliers are shown with grey dots and are defined as having a value which have values more than 1.5 times the interquartile range above the upper quartile and less than 1.5 times the interquartile range below the lower quartile 


\section{System-based approach}

Considering the PGF systems as the units rupturing in isolation, the moment magnitude estimations based on surface rupture lengths yield values ranging from $M_{\mathrm{w}} \approx 5.5-6.7$. The mean displacement values give moment magnitude ranges of $M_{\mathrm{w}} \approx 6.2-7.3$, the maximum displacement values give moment magnitude ranges of $M_{\mathrm{w}} \approx 6.7-8.0$ and the mean displacement values assuming dip values of $70^{\circ}$ and $80^{\circ}$ give moment magnitude ranges between $M_{\mathrm{w}} \approx 6.2-7.4$ and $M_{\mathrm{w}} \approx 6.2-7.3$, respectively. For the same dip values, the maximum displacements yield ranges of $M_{\mathrm{w}} \approx 6.7-8.1$ and $M_{\mathrm{w}} \approx 6.7-8.0$, respectively.

\section{Complex-based approach}

Assuming conservatively that the whole Suasselkä PGF complex ruptured in a single event, estimates of moment magnitudes based on the surface rupture length range from $M_{\mathrm{w}} \approx 7.1-7.4$, whereas estimates based on the mean and maximum vertical displacement respectively range from $M_{\mathrm{w}}$ $\approx 6.7-7.1$ and $M_{\mathrm{w}} \approx 6.9-8.0$. These correspond to a total surface rupture length of $59 \mathrm{~km}$, accounting for the sum of lengths of individual segments, and a mean and maximum cumulative displacement of $1.2 \mathrm{~m}$ and $7.7 \mathrm{~m}$. If the observed dip values are further taken into account, the mean displacements yield moment magnitudes from $M_{\mathrm{w}} \approx 6.7-7.2$ for both dip values and the maximum displacements moment magnitudes from $M_{\mathrm{w}} \approx 6.9-8.1$ for dip value of 70 degrees and $M_{\mathrm{w}} \approx 6.9-8.0$ for the dip value of $80^{\circ}$. It is noted that the scaling equations of Moss and Ross (2011) for maximum displacement values yield both quite small and large moment magnitudes with respect to the other scaling laws and parameters and may potentially to represent unrealistic estimates, as these are essentially outliers with respect to other moment magnitude predictors.

\section{Summary of the moment magnitude estimations}

In general, there is a discrepancy between the length- and displacement-based estimates, and this discrepancy is largest at the segment level analysis. This suggests that the rupturing unit was either at the system or complex level, with the complex-level estimates giving the largest compatibility between length- and displacement-based estimates (Fig. 13). We note that a similar discrepancy was observed by Ojala et al. (2017) in their analysis of the Isovaara-Riikonkumpu PGF complex, located a few tens of kilometers south of the Suasselkä PGF complex. Although we cannot exclude the possibility that certain segments or groups of segments ruptured individually, as explained above, we conservatively estimated the potential moment magnitudes of the paleoearthquakes that have taken place in the complex using a system- and complex-level approach. This gives a maximum moment magnitude estimate in the range of $M_{\mathrm{w}}$ $\approx 5.5-8.1$. If the estimates based on Moss and Ross (2011) are considered as extremes and excluded, then the potential range of moment magnitudes that the faults may have hosted ranges between $M_{\mathrm{w}} \approx 5.5-7.4$. We cannot, however, confirm whether the estimations based on Moss and Ross (2011) are indeed too extreme and, therefore, consider that $M_{\mathrm{w}} \approx 8.1$ represents a conservative maximum moment magnitude for the whole complex.

Ojala et al. (2019) employed landslide data in the estimation of potential moment magnitudes for postglacial faults in the Kolari region, but we note that the area in the vicinity of the Suasselkä PGF complex, and in particular the Suasselkä, Suasoja and Nilimaa PGF systems (Fig. 2), is essentially barren of landslides and we cannot, therefore, use such data for comparison.

The estimated moment magnitudes given here are generally in agreement with the estimates presented for other postglacial faults in Fennoscandia, which suggest paleoearthquakes with magnitudes in the range of $M_{\mathrm{w}} \approx 6.5-8.0$. The Pärvie fault in northern Sweden is considered to have hosted an earthquake with a moment magnitude range of up to $M_{\mathrm{w}} \approx 7.6-8$ (Lundqvistand and Lagerbäck 1976; Arvidsson 1996; Lindblom et al. 2015), the Stuoragurra fault in Norway an earthquake of $M_{\mathrm{w}} \approx 7.3$ (Olesen 1988), the Pasmajärvi-Venejärvi in Finland $M_{\mathrm{w}} \approx 6.5$ (Olesen et al. 2004), Lainio-Suijavaara in Sweden $M_{\mathrm{w}} \approx 7.1$ (Lagerbäck 1979), Lansjärv in Sweden $M_{\mathrm{w}} \approx 7.1$ (Lagerbäck 1979) and Vättern in Sweden $M_{\mathrm{w}} \approx 7.5$ (Jakobsson et al. 2014), and Isovaara-Riikonkumpu in the range of $M_{\mathrm{w}} \approx 6.9-7.5$ (Ojala et al. 2017). Our current estimate for the Suasselkä PGF complex is also consistent with earlier estimates for the Suasselkä fault, which are in the range of $M_{\mathrm{w}} \approx 7.0$ (Olesen et al. 2004).

\section{Geomorphic evidence of multiple fault rupturing events}

The characteristics of the terrain from LiDAR data and the relationship between the fault scarps and the diverse glacial geomorphology associated with ice-flow, glacial meltwater deposits and ancient shorelines offer a range of possibilities to date fault instability relative to deglaciation (Fig. 3). Close to the Suaspalo study site, the fault scarp is manifested by a drastic change in the strike of the fault and, in addition, the scarp consists of a main fault segment and two shorter segments that 'branch' off from the main segment (Fig. 3a). Such branching provides insights into the propagation history and mechanics of the faulting. The two smaller segments form an acute angle of c. $20-30^{\circ}$ with the main segment and strike in a more NE direction with respect to the ENE direction of the main segment. During the propagation 
of a seismic event within a fault, backward branching is never favored by prevailing stress states, and inferences can, therefore, be made from the relative orientations of fault segments and their branching relations (e.g., Fliss et al. 2005; Nakata et al. 1998). Based on this, if it is assumed that the segments formed coevally, the rupture must have propagated from SW to NE; otherwise, the minor segments would have formed through backward branching. Another possibility is that the segments formed during separate events in different time periods and through propagation in different directions and this may indeed be the case, as branching in opposite directions is observed throughout the complex (Fig. 14).

Fault slip profiles may also be utilized in the assessment of rupture directivity, as asymmetric displacement profiles are often considered to reflect propagation directions, and a decreasing displacement gradient also indicates the rupture direction (e.g., Manighetti et al. 2001; Davis et al. 2005). In the case of the Suasselkä PGF complex, no such tendency or clear gradient is observed, apart from a large cumulative displacement peak in the SW part of the complex, which is, however, an isolated peak with respect to the rest of the complex. Isolated segments show more or less elliptic and symmetric displacement profiles, which does not allow making definitive interpretations of the directivity of the whole complex. The data may, however, indicate that the cumulative propagation direction of the Sirkka PGF system was from SW to NE. Thus, based on the opposite branching directions in the Suasselkä PGF system, which the Suaspalo and Retu sites are part of, it is inferred that the segments must have formed during separate events and with rupture propagation in different directions, and that the system is a result of several seismic events, as also shown by the observations from the Suaspalo trench.

At several localities, the relationship between fault segments and morphological features connected with melt water distribution following the latest ice sheet retreat indicates that at least one faulting episode in the Suasselkä PGF system occurred after or in close connection with local deglaciation. For example, lateral drainage channels NE of Lake Suasjärvi are cut off by the fault ramp with an elevation difference of 1.5 to $2 \mathrm{~m}$ (Fig. 3c). Likewise, extra-marginal spillway channels and a larger subglacial drainage channel close to the Retu site are evidently split by the fault ramp indicating that the faulting is younger than or of the age of the latest deglaciation (Fig. 3b). Apart from the Suaspalo and Retu sites, the timing of the events is unknown. Earlier, Lagerbäck and Sundh (2008) discussed the possibility that the Lainio-Suijavaara fault scarps in northern Sweden have been formed in more than one episode of displacement, and that a two-step origin is evident for the short fault scarps at Storuman. However, similarly to northern Finland, reliable observations of older movement during an earlier phase of the Weichselian glaciation or Saalian glaciation are still very sparse, even in areas with a limited amount of glacial erosion during the most recent glaciations.

It has to be considered that the Suaspalo stratigraphy provides the first potential evidence of pre-Weichselian faulting in northern Finland. If this is the case, it indicates that at least some of the fault segments may have reactivated after several glaciations and, according conceptual model (Arvidsson 1996), in connection with the glacioisostatic rebound. This is in accordance with the hypothesis raised in northern Sweden, where Lundqvist and Lagerbäck (1976) and later Smith et al. (2018b) discussed the possibility that at least some segments in the Pärvie and Merasjärvi PGFs were activated during earlier interglacials or interstadials. Notably in this context, earthquake-induced soft sediment deformation structures caused by the Saalian glacioisostatic crustal rebound have been reported from interglacial successions

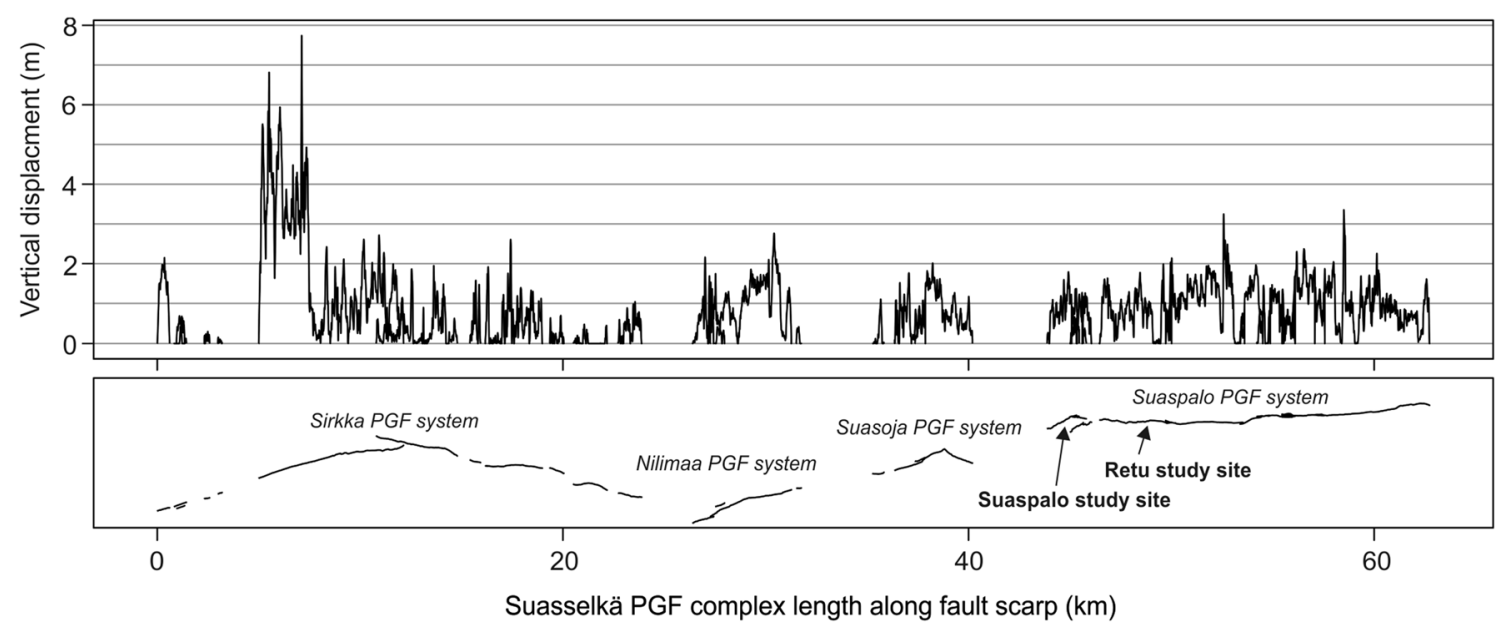

Fig. 14 Geometry and cumulative vertical displacement profile of the Suasselkä PGF complex 
in several places in Poland (e.g., Van Loon and PisarskaJamroży 2014; Pisarska-Jamroży et al. 2018).

It is likely that stratigraphic data alone from scattered trenches excavated across faults scarps during the last decades in Sweden and Finland do not provide sufficient evidence of multiple fault ruptures. In addition to that, careful consideration of the propagation of individual PGF segments, as well as examination of the terrain geomorphology in fault vicinities, are needed to understand characteristics of non-stationary seismicity and the phenomenon of multiple fault ruptures during and after the retreat of the Fennoscandian Ice Sheet. The Suaspalo case supports the hypothesis that multiple fault rupturing events are perhaps more common than previously thought, with a close connection to fault instability with old fault and fracture zones.

\section{Conclusions}

The combined use of geophysical, morphometrical and stratigraphical methods we applied here to detect characteristics of the Suasselkä postglacial fault system may be applicable to other areas, where PGFs are studied in recently glaciated terrains. Our studies at and in the surrounding of the Suaspalo and Retu study sites led to the following conclusions:

- Multiple rupturing events can take place within 'postglacial faults' in northern Fennoscandia, where different or the same PGF segments within a PGF system may have been active several times after the Late Weichselian glaciation or/and after glacial phases that predate the last glacial maximum. These results warrant re-evaluation of the long-term seismic risk associated with the faults as the assumption of single rupture events is overly conservative.

- The relationship between PGF segments and morphological features of glaciated terrain (e.g., extra-marginal spillway channels, larger subglacial drainage channels) at the Retu and Suaspalo study sites indicates that at least one faulting episode in the Suasselkä PGF system occurred after or in close connection with local deglaciation. This conclusion is supported by the surface lithostratigraphic observations from the excavated trenches.

- The Suasselkä PGF complex is composed four PGF systems and 37 isolated 150-7500-m-long PGF segments. Assuming that the entire complex ruptured in a single event, the observed displacement and length of the complex yields a moment magnitude estimate of $M_{\mathrm{w}} \approx$ 6.7-8.1. Based on geomorphological and sedimentological evidence, we believe that $M_{\mathrm{w}} \approx 8.1$ is a conservative (worst-case) estimate of the maximum moment magnitude of the paleoearthquake that took place in the com- plex. If isolated systems are considered to have ruptured individually, the moment magnitudes estimated based on surface rupture lengths range from $M_{\mathrm{w}} \approx 5.5-6.7$, and based on mean and maximum cumulative displacement values, the estimated values range from $M_{\mathrm{w}} \approx 6.2-7.3$ and $M_{\mathrm{w}} \approx 6.7-8.0$, respectively. As we cannot with the available data distinguish the exact number of events, the age of events or which segments potentially ruptured at the same time, we conclude that the events that took place in the complex ranged in moment magnitude from c. $M_{\mathrm{w}}$ $\approx 5.5$ to 8.1 .

Acknowledgements This paper is a part of the cooperation project PGSdyn carried out by Posiva and Geological Survey of Finland (GTK). We thank Ilkka Aro and Juha Majaniemi GTK for help during field surveys, and especially Jyrki Korteniemi (Agnico Eagle Finland) for logistical support during excavation. Lars Olsen and an anonymous reviewer are acknowledged for their constructive comments. This work was supported by the Academy of Finland via RAMI infrastructure project (\#293109).

Open Access This article is distributed under the terms of the Creative Commons Attribution 4.0 International License (http://creativeco mmons.org/licenses/by/4.0/), which permits unrestricted use, distribution, and reproduction in any medium, provided you give appropriate credit to the original author(s) and the source, provide a link to the Creative Commons license, and indicate if changes were made.

\section{References}

Ahjos T, Uski M (1992) Earthquakes in northern Europe in 1375-1989. Tectonophysics 207:1-23

Arvidsson R (1996) Fennoscandian earthquakes: whole crustal rupturing related to postglacial rebound. Science 274:744-746

Berglund M, Dahlström N (2015) Post-glacial fault scarp in Jämtland, central Sweden. GFF 137:339-343

Davis K, Burbank WD, Fisher D, Wallace S, Nobes D (2005) Thrustfault growth and segment linkage in the active Ostler fault zone, New Zealand. J Struct Geol 27:1528-1546

Fliss S, Bhat HS, Dmowska R, Rice JR (2005) Fault branching and rupture directivity. J Geophys Res 110:B06312

Hirvas H (1991) Pleistocene stratigraphy of Finnish Lapland. Geological Survey of Finland, Bulletin 354, 123 pp

Jakobsson M, Björck S, O'Regan M, Flodén T, Greenwood SL, Swärd $\mathrm{H}$ (2014) Major earthquake at the Pleistocene-Holocene transition in Lake Vättern, southern Sweden. Geology 42:379-382

Kujansuu R (1967) On the deglaciation of western Finnish Lapland. Bulletin de la commission géologique de Finlande 232:1-98

Lagerbäck R (1979) Neotectonic structures in northern Sweden. Geologiska Föreningens i Stockholm Förhandlingar 100:271-278

Lagerbäck R (1990) Late Quaternary faulting and paleoseismicity in northern Fennoscandia, with particular reference to the Lansjärv area, northern Sweden. Geologiska Föreningens i Stockholm Förhandlingar 112:333-354

Lagerbäck R, Sundh M (2008) Early Holocene faulting and paleoseismicity in northern Sweden. Geological Survey of Sweden, Research Paper C 836, 80 pp 
Larsen E, Mangerud J (1992) Subglacially formed clastic dikes. Sueriges Geologisha Undersdhning Serier Ca 81:163-170

Leonard M (2010) Earthquake Fault scaling: self-consistent relating of rupture length, width, average displacement, and moment release. Bull Seismol Soc Am 100:1971-1988

Lindblom E, Lund B, Tryggvason A, Uski M, Bodvarsson R, Juhlin C, Roberts R (2015) Microearthquakes illuminate the deep structure of the endglacial Parvie fault, northern Sweden. Geophys J Int 201:1704-1716

Lund B, Schmidt P, Hieronymus C (2009) Stress evolution and fault stability during the Weichselian glacial cycle, SKBF/KBS Technical Report 09-15, Swedish Nuclear Fuel and Waste Management Co, Stockholm, p 106

Lund B, Roberts R, Smith CA (2017) Review of paleo-, historical and current seismicity in Sweden and surrounding areas with implications for the seismic analysis underlying SKI report 92:3. Strål säkerhets myndigheten. Swedish Rad Saf Authority Rep 2017:35, $68 \mathrm{pp}$

Lundqvist J, Lagerbäck R (1976) The Pärve fault: A lateglacial fault in the Precambrian of Swedish Lapland. Geologiska Föreningens i Stockholm Förhandlingar 98:45-51

Manighetti I, King GCP, Gaudemer Y, Scholz C, Doubre C (2001) Slip accumulation and lateral propagation of active normal faults in Afar. J Geophys Res 106:13667-13696

Mikko H, Smith C, Lund B, Ask MV, Munier R (2015) LiDARderived inventory of post-glacial fault scarps in Sweden. GFF 137:334-338

Moss ES, Ross ZE (2011) Probabilistic fault displacement hazard analysis for reverse faults. Bull Seismol Soc Am 101:1542-1553

Munier R, Fenton C (2004) Current understanding and directions for future studies. In: Munier R and Hökmark H (eds.), Respect distances: Rationale and means of computation. Swedish Nuclear Fuel and Waste Management Co., Stockholm, Report R-04-17:157-218

Nakata T, Shimazaki K, Suzuki Y, Tsukuda E (1998) Fault branching and directivity of rupture propagation (in Japanese). J Geogr 107:512-528

Nordkalott Project (1986) Map of Quaternary Geology, Sheet 2: Glacial Geomorphology and Paleohydrography, Northern Fennoscandia, Scale 1:1 000 000. Geological Surveys of Finland, Norway and Sweden

Ojala AEK, Mattila J, Ruskeeniemi T, Palmu J-P, Lindberg A, Hänninen P, Sutinen R (2017) Postglacial seismic activity along the Isovaara-Riikonkumpu fault complex. Global Planet Change 157:59-72

Ojala AEK, Markovaara-Koivisto M, Middleton M, Ruskeeniemi T, Mattila J, Sutinen R (2018) Dating of seismically-induced paleolandslides in western Finnish Lapland. Earth Surf Proc Land 43:2449-2462

Ojala AEK, Mattila J, Markovaara-Koivisto M, Ruskeeniemi T, Palmu J-P, Sutinen R (2019) Distribution and morphology of landslides in northern Finland - analysis of postglacial seismic activity. Geomorphology 326:213-224

Olesen O (1988) The Stuoragurra Fault, evidence of neotectonics in the Precambrian of Finnmark, northern Norway. Nor Geol Tidsskr 68:107-118

Olesen O, Henkel H, Lile OB, Mauring E, Rønning JS (1992) Geophysical investigations of the Stuoragurra postglacial fault, Finnmark, northern Norway. J Appl Geophys 29:95-118
Olesen O, Blikra LH, Braathen A, Dehls JF, Olsen L, Rise L, Roberts D, Riis F, Faleide JI, Anda E (2004) Neotectonic deformation in Norway and its implications: a review. Norw J Geol 84:3-34

Olesen O, Bungum H, Dehls J, Lindholm C, Pascal C, Roberts D (2013) Neotectonics, seismicity and contemporary stressfield in Norway-mechanisms and implications. In: Olsen L, Fredin O, Olesen O (Eds.), Quaternary Geology of Norway. Geological Survey of Norway, Special Publication 13:145-174

Palmu J-P, Ojala AEK, Ruskeeniemi T, Sutinen R, Mattila J (2015) LiDAR DEM detection and classification of postglacial faults and seismically-induced landforms in Finland: a paleoseismic database. GFF 137:344-352

Peuraniemi V, Aario R, Pulkkinen P (1997) Mineralogy and geochemistry of the clay fraction of till in northern Finland. Sed Geol 111:313-327

Pisarska-Jamroży M, Van Loon AJ, Mleczak M, Roman M (2018) Enigmatic gravity-flow deposits at Ujście (western Poland), triggered by earthquakes (as evidenced by seismites) caused by Saalian glacioisostatic crustal rebound. Geomorphology. https://doi. org/10.1016/j.geomorph.2018.01.010

Salonen V-P, Moreau J, Hyttinen O, Eskola KO (2014) Mid-Weichselian interstadial in Kolari, western Finnish Lapland. Boreas 43:627-638

Smith C, Sundh M, Mikko H (2014) Surficial geologic evidence for early Holocene faulting and seismicity. Int J Earth Sci 103:1711-1724

Smith CA, Nyberg J, Bergman B (2018a) Comparison between hydroacoustical and terrestrial evidence of glacially induced faulting, Lake Voxsjön, central Sweden. Int J Earth Sci 107:169-175

Smith CA, Grigull S, Mikko H (2018b) Geomorphic evidence of multiple surface ruptures of the Merasjärvi "postglacial fault", northern Sweden. GFF. https://doi.org/10.1080/11035897.2018.1492963

Sutinen R (1992) Glacial deposits, their electrical properties and surveying by image interpretation and ground penetrating radar. Bull Geol Survey Finland 359:123 pp

Sutinen R, Hyvönen E, Middleton M, Ruskeeniemi T (2014a) Airborne LiDAR detection of postglacial faults and Pulju moraine in Palojärvi, Finnish Lapland. Global Planet Change 115:24-32

Sutinen R, Hyvönen E, Kukkonen I (2014b) LiDAR detection of paleolandslides in the vicinity of the Suasselkä postglacial fault, Finnish Lapland. Int J Appl Earth Obs Geoinf 27:91-99

Uski M, Hyvönen T, Korja A, Airo M-L (2003) Focal mechanisms of three earthquakes in Finland and their relation to surface faults. Tectonophysics 363:141-157

Van Loon AJ, Pisarska-Jamroży M (2014) Sedimentological evidence of Pleistocene earthquakes in NW Poland induced by glacio-isostatic rebound. Sed Geol 300:1-10

Wells DL, Coppersmith KJ (1994) New empirical relationships among magnitude, rupture length, rupture width, rupture area, and surface displacement. Bull Seismol Soc Am 84:974-1002

Wesnousky SG (2006) Predicting the endpoints of earthquake ruptures. Nature 444:358-360

Wesnousky SG (2008) Displacement and geometrical characteristics of earthquake surface ruptures: issues and implications for seismichazard analysis and the process of earthquake rupture. Bull Seismol Soc Am 98:1609-1632

Wu P, Johnston P, Lambeck K (1999) Postglacial rebound and fault instability in Fennoscandia. Geophys J Int 139:657-670 